\title{
Global distribution and climate forcing of marine organic aerosol - Part 2: Effects on cloud properties and radiative forcing
}

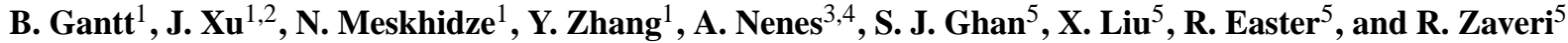 \\ ${ }^{1}$ Department of Marine, Earth, and Atmospheric Sciences, North Carolina State University, Raleigh, NC, USA \\ ${ }^{2}$ Chinese Research Academy of Environment Sciences, No. 8 Dayangfang, Beiyuan, Chaoyang District, \\ Beijing 100012, China \\ ${ }^{3}$ School of Earth and Atmospheric Sciences, Georgia Institute of Technology, Atlanta, GA, USA \\ ${ }^{4}$ School of Chemical and Biomolecular Engineering, Georgia Institute of Technology, Atlanta, GA, USA \\ ${ }^{5}$ Atmospheric Sciences \& Global Change Division, Pacific Northwest National Laboratory, Richland, WA, USA
}

Correspondence to: N. Meskhidze (nmeskhidze@ncsu.edu)

Received: 8 February 2012 - Published in Atmos. Chem. Phys. Discuss.: 15 March 2012

Revised: 5 July 2012 - Accepted: 6 July 2012 - Published: 25 July 2012

\begin{abstract}
A series of simulations with the Community Atmosphere Model version 5 (CAM5) with a 7-mode Modal Aerosol Model were conducted to assess the changes in cloud microphysical properties and radiative forcing resulting from marine organic aerosols. Model simulations show that the anthropogenic aerosol indirect forcing (AIF) predicted by CAM5 is decreased in absolute magnitude by up to $0.09 \mathrm{~W} \mathrm{~m}^{-2}(7 \%)$ when marine organic aerosols are included. Changes in the AIF from marine organic aerosols are associated with small global increases in low-level incloud droplet number concentration and liquid water path of $1.3 \mathrm{~cm}^{-3}(1.5 \%)$ and $0.22 \mathrm{~g} \mathrm{~m}^{-2}(0.5 \%)$, respectively. Areas especially sensitive to changes in cloud properties due to marine organic aerosol include the Southern Ocean, North Pacific Ocean, and North Atlantic Ocean, all of which are characterized by high marine organic emission rates. As climate models are particularly sensitive to the background aerosol concentration, this small but non-negligible change in the AIF due to marine organic aerosols provides a notable link for ocean-ecosystem marine low-level cloud interactions and may be a candidate for consideration in future earth system models.
\end{abstract}

\section{Introduction}

Marine organic aerosols, emitted into the atmosphere as primary particles via bursting of bubbles at the ocean surface and secondary particles via oxidation of volatile organic compounds (VOC) such as isoprene, monoterpenes, amines, and dimethyl sulfide (DMS), have been shown to affect the chemistry and number distribution of aerosols in the marine environment (O'Dowd et al., 2004; Meskhidze and Nenes, 2006; Yoon et al., 2007; Facchini et al., 2008). Part 1 of this study (Meskhidze et al., 2011) described the implementation of marine organic aerosols in the Community Atmosphere Model version 5 (CAM5) with a 7-mode Modal Aerosol Module (MAM-7) (Liu et al., 2012). Meskhidze et al. (2011) showed that addition of marine organics led to improved agreement of the model predicted and measured concentrations of organic aerosols in the marine boundary layer, with annual average submicron aerosol mass concentration increased by up to $400 \mathrm{ng} \mathrm{m}^{-3}$ over biologically active oceanic regions. Comparison with long-term observations showed that of the two marine primary organic emission parameterizations implemented into CAM5 (Vignati et al., 2010; Gantt et al., 2011), the Gantt et al. (2011) emissions were slightly better in replicating the seasonal cycle of water insoluble organic aerosol mass concentrations. In the areas with the highest emission rates of marine organic aerosols, the cloud condensation nuclei (CCN) concentrations increased by up 
to $20 \%$ due to an increase in the accumulation mode (80$300 \mathrm{~nm}$ in diameter in CAM5) aerosol number concentration.

The potential influence of marine organic aerosols on cloud microphysical properties and radiative forcing was first discussed by Novakov and Penner (1993) and Novakov et al. (1997), who found that organic aerosols of marine origin contributed to a major fraction of marine boundary layer CCN concentration in the Tropical Atlantic. O'Dowd et al. (2004) described an increase (15-100\%) in cloud droplet number concentration (CDNC) at Mace Head with the inclusion of marine organic aerosols derived from size-resolved chemistry and number distribution measurements. Ovadnevaite et al. (2011) reported similar results in an aerosol mass spectrometer study at Mace Head, finding that periods with high organic fractions and low growth factors also had a higher weighted average particle size, CCN activation efficiency, and estimated CDNC. In a modeling study, Roelofs (2008) reported results from the ECHAM5-HAM model in which marine organic aerosols increased North Atlantic CDNC by a factor of 3-4 ( 35 to $\left.120 \mathrm{~cm}^{-3}\right)$ and decreased cloud effective radius from $15-20 \mu \mathrm{m}$ to $10-14 \mu \mathrm{m}$ in diameter. These changes brought the model closer to satellite derived values for the region. However, not all studies examining the potential climate impact of marine organic aerosols have found that they have a large impact. Hygroscopic and CCN activity measurements of laboratory bubble bursting experiments from Fuentes et al. (2011) and Moore et al. (2011) found that despite evidence of organic compounds in sea spray aerosol, their higher hydrophobicity and lower CCN activity lead to a prediction of small changes in $\mathrm{CCN}$ concentration associated with marine organic aerosols and negligible impact on cloud formation. Westervelt et al. (2012) suggested that marine organic aerosols have a minor impact on climate due to GISS II-prime modeling results showing a decrease in $\mathrm{CCN}$ concentration (due to a decrease in particle solute concentration) in all simulation except when marine organic aerosols and sea-salt were treated as externally-mixed. Here in the second part of the study for climate forcing of marine organic aerosol, we focus on the impact of the marine organic aerosols on cloud microphysical properties and shortwave radiative forcing.

\section{Model experimental setup}

To detect the specific effects of marine organics on aerosol and cloud properties, various sensitivity simulations expanding upon the simulations in Meskhidze et al. (2011) have been performed. We use the National Center of Atmospheric Research (NCAR)'s Community Atmosphere Model (CAM5) with the Pacific Northwest National Laboratory's 7-mode Modal Aerosol Module (MAM-7) for both Part 1 and Part 2 of this study. CAM5 general circulation model with a complete representation of the aerosol lifecycle, a physically-based treatment of aerosol activation, double-
Table 1a. Description of the CAM5 simulations ${ }^{\mathrm{a}}$ in the Part 1 paper that are further analyzed here in this work (i.e., the Part 2 paper).

\begin{tabular}{ll}
\hline Simulation & Emissions \\
\hline Default $^{\mathrm{b}}$ & $\begin{array}{l}\text { sulfur dioxide, sulfate, terrestrial POA, } \\
\text { terrestrial SOA, black carbon, ammonia, dust, } \\
\text { DMS, sea-salt }\end{array}$ \\
SOA/MS $^{-}$ & $\begin{array}{l}\text { Same as Default but with marine SOA, MS } \\
\text { G11 }\end{array}$ \\
& $\begin{array}{l}\text { Same as Default but with Gantt et al. (2011) } \\
\text { marine POA emissions externally-mixed with } \\
\text { sea-salt, marine SOA, MS }\end{array}$ \\
G11-Internal & $\begin{array}{l}\text { Same as G11, except marine POA } \\
\text { emissions internally-mixed with sea-salt, no } \\
\text { marine SOA or MS }\end{array}$ \\
\hline
\end{tabular}

${ }^{a}$ Simulations used the Abdul-Razzak and Ghan (2000) aerosol activation parameterization

b Simulations were 10-yr long (instead of the typical 5-yr) with a 3-month spinup

moment cloud microphysics, and interactive cloud radiative properties. The model simulations are conducted at $1.9^{\circ} \times 2.5^{\circ}$ horizontal grid resolution with a vertical resolution of 30 layers from the surface to $2.19 \mathrm{hPa}$. CAM5/MAM7 (hereinafter referred to as CAM5) treats aerosols as internal mixtures of all major species within each of seven externallymixed modes. A detailed description of CAM5 can be found at http://www.cesm.ucar.edu/models/cesm1.0/cam and Neale et al. (2010). In the Part 1 simulations, the "Default" simulation in which there are no marine organic aerosols was compared to simulations which included production of marine secondary organic aerosol (SOA) and methane sulfonate $\left(\mathrm{MS}^{-}\right.$) ("SOA/MS" ") and marine POA emissions (Gantt et al., 2011) that were either externally- ("G11") or internallymixed ("G11-Internal"). When the marine POA emissions were externally-mixed, they resulted in additional aerosol number and mass in the four model modes (Aitken, accumulation, and fine/coarse sea-salt modes) as opposed to only additional aerosol mass for the internally-mixed marine POA emissions.

The emissions from the G11 simulation in Part 1 are used in the sensitivity simulations for this work because the resulting surface concentrations had a seasonal cycle that was more similar to observations. These sensitivity simulations are carried out to determine the impact of marine organic aerosols on cloud microphysics and radiative forcing for different aerosol activation parameterizations and marine POA hygroscopicity and mixing state. Table 1 gives a summary of the 10- and 5-yr long simulations with 3-month spin-up, including those performed in Part 1 on which the simulations in this work are based. Detailed descriptions of the different aerosol activation schemes, marine POA hygroscopicity and mixing state treatments, and preindustrial and present day anthropogenic emissions can be found in Meskhidze et al. (2011). In addition to simulations using the Abdul-Razzak and Ghan (2000) (hereinafter referred to as AR-G) aerosol 
Table 1b. Description of additional CAM5 simulations.

\begin{tabular}{|c|c|c|}
\hline Simulation & Emissions & Setup \\
\hline Default-PI ${ }^{\mathrm{a}}$ & $\begin{array}{l}\text { Same as Default but with } \\
\text { anthropogenic emissions set to } \\
\text { year } 1850\end{array}$ & Same as Default \\
\hline Default-FN & Same as Default & $\begin{array}{l}\text { Uses the Fountoukis and Nenes (2005) (FN) } \\
\text { aerosol activation parameterization }\end{array}$ \\
\hline G11-FN & Same as G11 & $\begin{array}{l}\text { Uses the }(\mathrm{FN}) \text { aerosol activation } \\
\text { parameterization }\end{array}$ \\
\hline $\mathrm{G} 11-\mathrm{PI}^{\mathrm{a}}$ & $\begin{array}{l}\text { Same as G11 but with anthropogenic } \\
\text { emissions set to year } 1850\end{array}$ & Same as G11 \\
\hline $\mathrm{G} 11-\kappa$ & Same as G11 & $\begin{array}{l}\text { Same as G11 but with hygroscopicity value } \\
(\kappa) \text { for marine POA set to } 0.1\end{array}$ \\
\hline
\end{tabular}

${ }^{a}$ Simulations were 10-yr long (instead of the typical 5-yr) with a 3-month spinup.

activation parameterization from Part 1, the aerosol activation parameterization described by Fountoukis and Nenes (2005) (hereafter referred to as FN) is implemented in simulations with and without the G11 marine organic emissions ("Default-FN" and "G11-FN", respectively). An additional sensitivity test was conducted for the hygroscopicity parameter $(\kappa)$ (Petters and Kreidenweis, 2007) of marine POA by increasing it (in the G11 simulation) from the $\kappa=10^{-10}$ value used for terrestrial POA to $\kappa=0.1$ ("G11- $\kappa$ ") (Liu et al., 2012). This adjusted $\kappa$ represents the upper end of the potential marine POA hygroscopicity based on the measurements of $\kappa$ values of 0.006 and 0.04 for estuarine (Moore et al., 2008) and riverine (Svenningsson et al., 2006) organic matter, respectively. In order to estimate the effect of marine organic aerosols on cloud radiative forcing, both the Default and G11 simulations were performed with present-day (PD) ("Default" and "G11") and pre-industrial (PI) aerosol and precursor emissions ("Default-PI" and "G11-PI"). The anthropogenic aerosol indirect forcing (AIF) is then calculated as the difference in model-predicted short wave cloud forcing (SWCF) between PD and PI conditions. The model simulations with PD and PI emissions used anthropogenic emissions from the IPCC AR5 dataset for the year 2000 and 1850, respectively (Bond et al., 2007; Junker and Liousse, 2008; Lamarque et al., 2010).

\section{Results}

As shown in Meskhidze et al. (2011), treating marine organic aerosols increased the simulated aerosol mass and CCN concentration over much of the ocean. Here we expand upon these results by carrying out a number of sensitivity tests for additional model parameters with the emphasis on the changes in cloud microphysics and radiative forcing associated with marine organic aerosols. Unless specified otherwise, the reported changes are relative to the Default simulation.

\subsection{Effects on cloud physical properties}

\subsubsection{Low-level cloud droplet number}

In general it is expected that the addition of $\mathrm{CCN}$ may result in an increase in the in-cloud CDNC if the liquid water path (LWP) is held constant (Twomey, 1972, Albrect, 1989). Current simulations show that, when LWP is unconstrained, addition of marine organic aerosols can change both CDNC and LWP of the clouds. The effect is expected to be particularly pronounced for the low-level maritime clouds as marine aerosols are typically found within $1 \mathrm{~km}$ above the ocean surface (Kiliyanpilakkil and Meskhidze, 2011). Table 2 shows that compared to the Default simulation, the global annual mean increase in low-level CDNC (between 945 and $980 \mathrm{mb}$ ) from marine organics in the G11 simulation is $1.3 \mathrm{~cm}^{-3}$ $(1.5 \%)$ while over the ocean CDNC increases by $1.8 \mathrm{~cm}^{-3}$ $(2.7 \%)$. The spatial distribution of low-level CDNC from the Default and G11 simulations shown in Fig. 1a and 1b reveals that the increase occurs mostly over the Southern Ocean and Northern Atlantic. Many of these areas also have the greatest percentage changes (up to $20 \%$ ) in CDNC as shown in Fig. $1 \mathrm{c}$ and are statistically significant (with a $p$-value $<0.1$ according to the paired t-test). Fig. 1c also shows some areas with decreases in low-level CDNC; these changes are typically not statistically significant, and are likely due to model noise. The spatial distribution of low-level CDNC percentage changes is similar to the percentage changes in the surface concentration of $\mathrm{CCN}$ at $0.2 \%$ supersaturation shown in Meskhidze et al. (2011). The magnitude of low-level CDNC changes in our simulations is much lower than the increases of up to $\sim 300 \%$ predicted in Roelofs (2008) for the Northern Atlantic Ocean; this difference is likely due to the much higher submicron marine organic aerosol number concentration in Roelofs (2008) resulting from higher emission rates (Roelofs (2008) has up to $25 \mathrm{Tg} \mathrm{C} \mathrm{yr}^{-1}$ of emissions in both the Aitken and accumulation modes while G11 emits 0.1 and 
Table 2. CAM5 modeled mean liquid cloud properties.

\begin{tabular}{lcccccccc}
\hline Simulation & \multicolumn{2}{c}{ Low-level CDNC $\left(\mathrm{cm}^{-3}\right)^{\mathrm{a}}$} & \multicolumn{2}{c}{ Column CDNC $\left(\times 10^{9} \mathrm{~m}^{-2}\right)^{\mathrm{b}}$} & \multicolumn{2}{c}{ LWP $\left(\mathrm{g} \mathrm{m}^{-2}\right)^{\mathrm{b}}$} & \multicolumn{2}{c}{$\mathrm{SWCF}\left(\mathrm{W} \mathrm{m}{ }^{-2}\right)$} \\
\hline & Global & Ocean & Global & Ocean & Global & Ocean & Global & Ocean \\
Default & 86.86 & 64.15 & 12.86 & 8.85 & 46.19 & 39.10 & -47.08 & -48.64 \\
SOA/MS & 85.34 & 63.62 & 12.88 & 8.80 & 46.05 & 38.90 & -47.08 & -48.59 \\
G11 & 88.13 & 65.91 & 13.00 & 8.98 & 46.41 & 39.24 & -47.20 & -48.69 \\
G11-Internal & 84.93 & 62.80 & 12.77 & 8.77 & 45.92 & 38.86 & -47.07 & -48.63 \\
Default-PI & 58.15 & 48.69 & 8.46 & 6.66 & 41.89 & 36.13 & -45.70 & -47.46 \\
Default-FN & 113.51 & 90.83 & 17.81 & 13.51 & 51.16 & 45.10 & -49.40 & -51.57 \\
G11-FN & 114.68 & 92.27 & 17.95 & 13.62 & 51.37 & 45.26 & -49.54 & -51.72 \\
G11-PI & 59.52 & 50.54 & 8.60 & 6.83 & 42.16 & 36.44 & -45.91 & -47.66 \\
G11- $\kappa$ & 86.11 & 64.82 & 12.93 & 8.94 & 46.09 & 39.06 & -47.18 & -48.72 \\
\hline
\end{tabular}

a Averaged from 945-980 mb;

b Calculated by using the grid-cell mean.

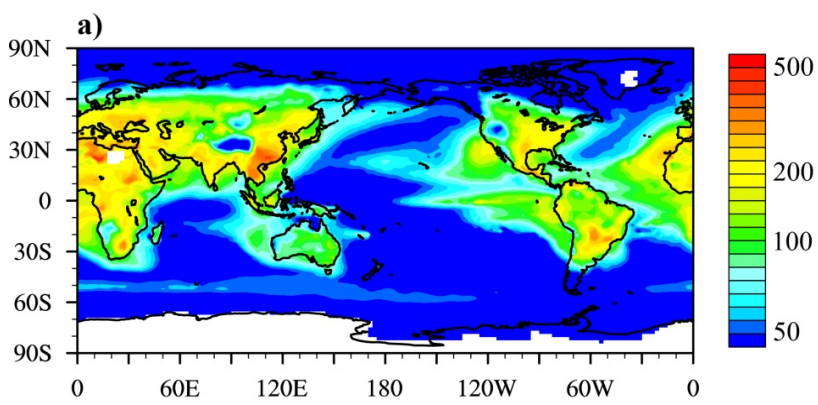

b)
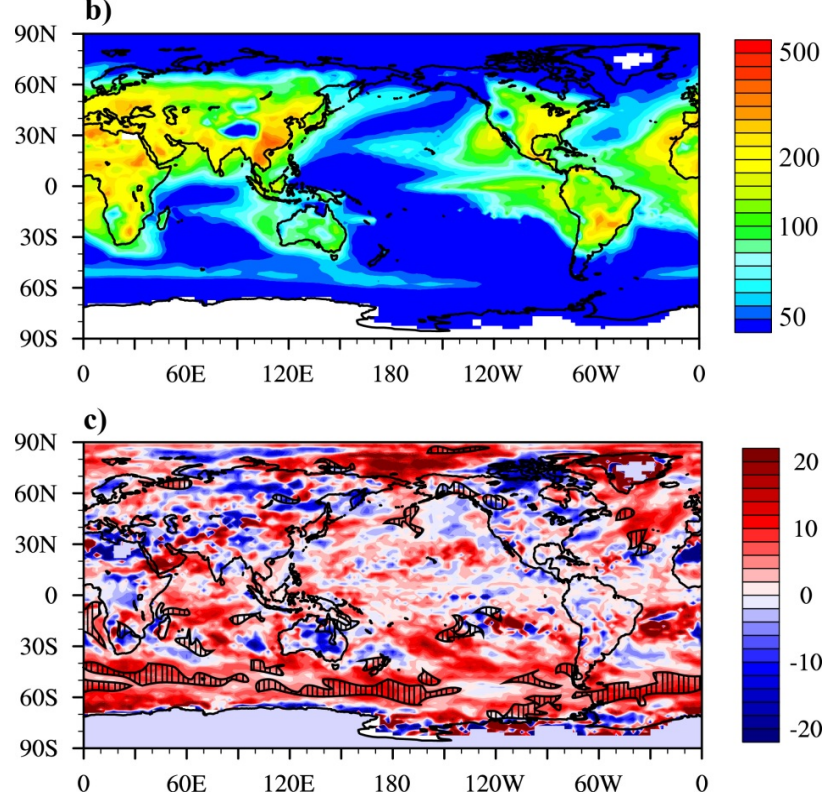

Fig. 1. Model predicted the 10-yr average in-cloud droplet number concentration $\left(\mathrm{cm}^{-3}\right)$ from $940-985 \mathrm{mb}$ for the (a) Default and (b) G11 simulations and the (c) percentage (\%) change between the two simulations. Striped areas in Fig. 1c have 10 or more contiguous model grids with significant $(p$-value of paired t-test $<0.1$ ) differences between the G11 and Default simulations.
2.1 $\mathrm{Tg} \mathrm{Cyr}^{-1}$ in the marine POA Aitken and accumulation modes, respectively).

\subsubsection{Column cloud properties and radiative forcing}

In addition to increases in low-level CDNC, marine organic aerosols in CAM5 lead to changes in the grid-cell averaged column CDNC, LWP, and SWCF. Like the low-level CDNC, the column CDNC (see Fig. 2a) experiences statistically significant increases of up to $20 \%$ over the Southern Ocean where emissions are the highest. Globally, the percentage increases in column droplet number from the Default to the G11 simulation of $1.1 \%(1.5 \%$ over the ocean) is smaller than that of low-level CDNC (see Table 2) as marine organic aerosol typically remain within the boundary layer. For the LWP, Fig. $2 b$ shows that despite the seemingly random regions of positive and negative changes between the Default and G11 simulations, there are widespread areas over the Southern Ocean that experience a large (up to $20 \%$ ) increase in the LWP as a result of marine organic aerosols. The spatial distribution of the changes in SWCF shown in Fig. 2c is similar to that of LWP with roughly $10 \%$ decreases $\left(\sim-5 \mathrm{~W} \mathrm{~m}^{-2}\right)$ in the vicinity of Falkland $\left(52^{\circ} \mathrm{S}, 58^{\circ} \mathrm{W}\right)$ and South Georgia Islands $\left(54^{\circ} \mathrm{S}, 36^{\circ} \mathrm{W}\right)$ in the South Atlantic Ocean where emissions of marine organic aerosols are very high. Note that the SWCF has a negative value; therefore decrease in SWCF indicates less solar radiation reaching the surface and shows as a positive percentage change in Fig. 2c. Like other higher latitude areas, the changes (absolute difference as opposed to percentage difference) in SWCF due to marine OA show a seasonal dependence similar to that of [Chl- $a$ ] (see Fig. S1). The spatial location of this large decrease in SWCF is similar to Meskhidze and Nenes (2006) who reported a satellite-derived $15 \mathrm{~W} \mathrm{~m}^{-2}$ decrease in TOA short-wave radiation due to changes in the properties of liquid clouds over a summertime phytoplankton bloom near South Georgia Island. The discrepancies in magnitude are likely to be associated with the coarser model 
grid, annual averaging (summertime SWCF changes of -5 to $-10 \mathrm{~W} \mathrm{~m}^{-2}$ are predicted throughout the region), selection by Meskhidze and Nenes (2006) of a time period with a particularly large phytoplankton bloom, and the effect of DMS-derived sulfate aerosols. Since the same DMS emissions are used in the Default and G11 simulations, DMSderived sulfate aerosols are likely to have a minor influence on the modeled changes in SWCF. Globally, the changes in the LWP and SWCF are much smaller relative to the region near South Georgia Island. Table 2 shows that there is a $0.22 \mathrm{~g} \mathrm{~m}^{-2}(0.5 \%)$ global average increase in the LWP in the G11 simulation relative to the Default simulation, and a $0.12 \mathrm{~W} \mathrm{~m}^{-2}(0.3 \%)$ decrease (indicating the increased reflection of shortwave radiation) in the SWCF. Like low-level CDNC, there is a seasonality in the absolute differences of column CDNC, LWP, and SWCF between the G11 and Default simulations at some high latitude areas that is similar to the $[$ Chl- $a]$ seasonality.

\subsection{Sensitivity simulations}

\subsubsection{Aerosol activation parameterizations}

Table 2 shows that AR-G and FN aerosol activation parameterizations give considerably different global low-level CDNC, LWP, and SWCF values (Default vs. Default-FN). Ghan et al. (2011) showed that these differences produce a $0.16 \mathrm{~W} \mathrm{~m}^{-2}(10 \%)$ smaller anthropogenic AIF with the FN scheme $\left(-1.60 \mathrm{~W} \mathrm{~m}^{-2}\right.$ with $\mathrm{FN}$ and $-1.76 \mathrm{~W} \mathrm{~m}^{-2}$ with AR-G). In current sensitivity simulation, the changes due to marine organic aerosols are relatively consistent between the two schemes (Default vs. G11 and Default-FN vs. G11FN). The global changes predicted for low-level CDNC, LWP, and SWCF (due to marine organic aerosol emissions) differ slightly between simulations that use FN-scheme $\left(1.2 \mathrm{~cm}^{-3}, 0.21 \mathrm{~g} \mathrm{~m}^{-2}\right.$, and $-0.14 \mathrm{~W} \mathrm{~m}^{-2}$, respectively) and the ones that use AR-G scheme $\left(1.3 \mathrm{~cm}^{-3}, 0.22 \mathrm{~g} \mathrm{~m}^{-2}\right.$, and $-0.12 \mathrm{~W} \mathrm{~m}^{-2}$, respectively). Therefore, our simulations indicate that the differences between the AR-G and FN aerosol activation parameterizations appear to be less sensitive to minor changes in $\mathrm{CCN}$ concentrations (such as from marine organic aerosols) compared to major changes (such as from anthropogenic aerosols).

\subsubsection{Marine POA missing state}

In Meskhidze et al. (2011), the changes in surface CCN concentration at $0.2 \%$ supersaturation were shown to be quite sensitive to the mixing state of marine POA emissions, with an external mixture (added marine POA mass emissions are accompanied by corresponding increases to sea spray number emissions) yielding a much greater effect on CCN number compared to an internal mixture (only the sea spray aerosol mass is enhanced by addition of organics). Table 2 shows that relative to the G11 simulation, which includes an
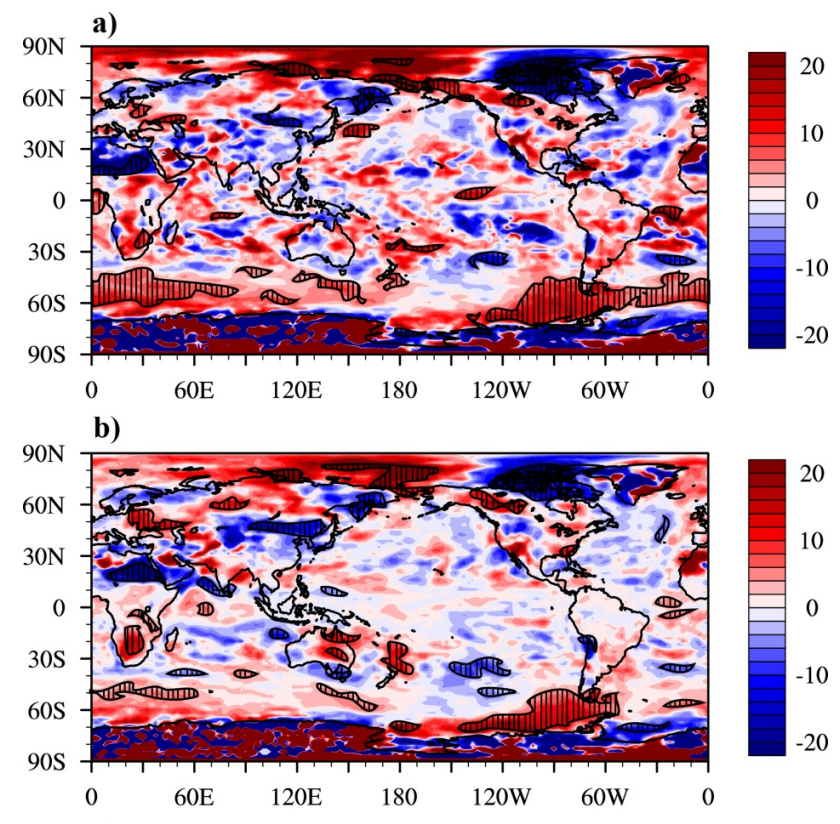

c)

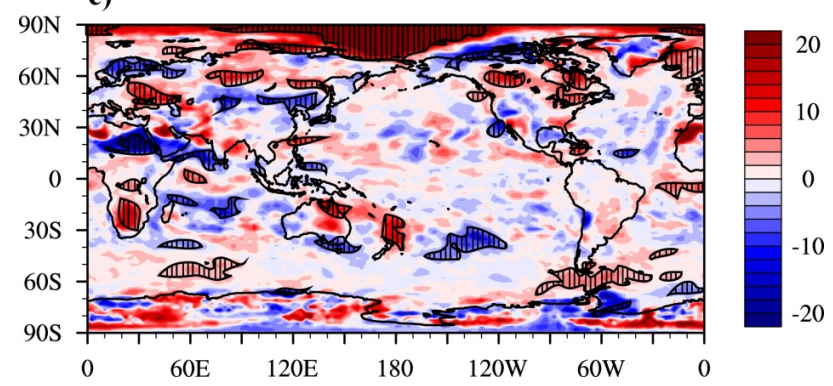

Fig. 2. Model predicted percentage change between the G11 and Default in the 10-yr average grid-mean column (a) cloud droplet number, (b) liquid water path, and (c) shortwave cloud forcing by marine emissions. Striped areas have 10 or more contiguous model grids with significant ( $p$-value of paired t-test $<0.1$ ) differences between the G11 and Default simulations.

external mixture of marine POA emissions, the simulation with an internal mixture of marine POA emissions (G11Internal) has consistently lower CDNC and LWP and higher (lower absolute magnitude) SWCF. Meskhidze et al. (2011) showed that when marine organics were added as an internal mixture with sea-salt the model predicted a slight reduction in CCN concentration, even over biologically productive waters of the Southern Ocean. In such a case the increase in $\mathrm{CCN}$ number due to the growth of mean modal diameter (caused by the addition of organic mass) is outweighed by the decrease in particle hygroscopicity. As both external and internal mixtures of marine organic aerosols and sea salt have been observed (Hultin et al., 2010), these mixing state differences likely represent upper and lower estimates for the effect of marine organic aerosol on cloud microphysical properties and resulting shortwave radiative forcing. 


\subsubsection{Hygroscopicity}

A change in value of $\kappa$ for marine POA from $10^{-10}$ used for G11 to 0.1 (as was used for terrestrial POA in the sensitivity tests of Liu and Wang, 2010) is expected to yield more $\mathrm{CCN}$ at relevant supersaturations and hence a greater impact on cloud properties and radiative forcing. However, Table 2 shows that the global and annual mean values from the G11 simulation and the G11- $\kappa$ (the simulation identical to G11 but with marine POA $\kappa$ increased to 0.1 ) reveal this not to be the case; model predicted low-level CDNC, LWP, and SWCF in the G11- $\kappa$ simulation are nearly equivalent to those of the G11 simulation. This small change in cloud properties due to changing organic aerosol hygroscopicity is similar to the slight change in global surface $\mathrm{CCN}$ at $0.2 \%$ supersaturation, which only increased from the $184.5 \mathrm{~cm}^{-3}$ reported in Meskhidze et al. (2011) to $185.0 \mathrm{~cm}^{-3}(0.3 \%)$ in $\mathrm{G} 11-\kappa$. There are two likely reasons for this insensitivity to aerosol hygroscopicity: (1) the aging method of aerosols in CAM5 based on a criterion of 3 mono-layers of sulfate, and (2) the hygroscopicity-dependent wet removal rates in CAM5 (Liu et al., 2012). Non-seasalt sulfate concentrations within the marine boundary layer are relatively high $\left(>0.2 \mu \mathrm{g} \mathrm{m}^{-3}\right)$ over productive waters where most of the marine POA emissions are coincident with strong DMS emissions; this causes the modeled aerosol aging in these areas to be more rapid than in oceanic areas without strong DMS emissions. As a result, cloud properties and SWCF are not sensitive to the hygroscopicity of the freshly-emitted marine POA, but rather to the $\kappa$ value of aged marine POA which is the same in G11 and G11- $\kappa$. This insensitivity to the POA hygroscopicity due to sufficient aging by sulfate has been observed previously in internally-mixed particles (as are simulated by CAM5), particularly over the industrial regions (Chang et al., 2007; Prenni et al., 2007; Wang et al., 2008; Liu and Wang, 2010; Liu et al., 2012). Furthermore, the atmospheric lifetime and burden of marine POA have an inverse relationship with hygroscopicity because more hygroscopic aerosols experience wet scavenging before those with low hygroscopicity (Liu et al., 2012). As a result, the increase in CCN (at a given supersaturation) due to higher hygroscopicity is offset somewhat by the decrease due to more rapid wet removal.

\subsubsection{Preindustrial and present day anthropogenic emissions}

It has been well documented that increased anthropogenic emissions since the beginning of the industrial revolution have an impact on the present day aerosol burden and associated cloud microphysical properties. Here we examine how the climate forcing due to changes between PI and PD emissions may be influenced by marine organic aerosols. In this set of simulations, all parameters are held constant except for the anthropogenic aerosol and precursor emissions: the Default and G11 simulations use emissions for the year
2000, while the Default-PI and G11-PI simulations use emissions for the year 1850. Recent studies suggest considerable decline (more than $6 \%$ ) in ocean primary productivity over the past decade likely attributed to anthropogenic activities and associated climate change (Bopp et al., 2001; Gregg et al., 2003; Behrenfeld et al., 2006). However, the difficulties in separating the natural variability from the global climate change trend has also been proposed (Henson et al., 2010). Due to the absence of reliable ocean productivity data for PI conditions, we use the same monthly chlorophyll- $a$ concentrations (effectively resulting in the same primary and precursor emissions for marine organic aerosols) for both G11 and G11-PI simulations. Table 2 shows that the addition of marine organics has a larger impact on cloud properties for simulations with PI emissions (differences between G11-PI and Default-PI) compared to the simulations with PD emissions (differences between G11 and Default). The global and annual mean differences in PI low-level CDNC, LWP, and SWCF are $1.4 \mathrm{~cm}^{-3}(2.4 \%), 0.27 \mathrm{~g} \mathrm{~m}^{-2}(0.6 \%)$ and $-0.21 \mathrm{~W} \mathrm{~m}^{-2}(0.5 \%)$, respectively, while the mean differences over the ocean are $1.9 \mathrm{~cm}^{-3}(3.8 \%), 0.31 \mathrm{~g} \mathrm{~m}^{-2}$ $(0.9 \%)$ and $-0.20 \mathrm{~W} \mathrm{~m}^{-2}(0.4 \%)$, respectively. The difference in the climatic effect of marine organic aerosol with and without high levels of anthropogenic aerosols is due to the higher susceptibility of preindustrial clouds to additional aerosols (Platnick and Twomey, 1994; Lohmann and Lesins, 2002). Specifically, these simulations show that additional $\mathrm{CCN}$ from marine organic aerosol emissions affect the properties of clouds in clean regions more than those in polluted regions. This result is consistent with the study by Hoose et al. (2009) where the slope of the change in SWCF between PI and $\mathrm{PD}$ emissions decreases with increases in the prescribed aerosol concentration.

\section{Aerosol indirect forcing}

The effect of marine organic aerosols on anthropogenic AIF is explored for various model configurations. Calculations show that marine organic aerosols reduce the absolute magnitude of the global average AIF from a default value of $-1.38 \mathrm{~W} \mathrm{~m}^{-2}$ to $-1.29 \mathrm{~W} \mathrm{~m}^{-2}$ (an $7 \%$ change) when comparing the Default/Default-PI and G11/G11-PI differences. Although Wang et al. (2011) suggested that the sensitivity of SWCF to changes in aerosol loading may be too strong in CAM5, this is not expected to have considerable influence on the relative effect of marine organic aerosols. This change in AIF by the marine $\mathrm{OA}\left(+0.09 \mathrm{~W} \mathrm{~m}^{-2}\right)$ is similar in magnitude to the SWCF changes between the Default and G11 simulations for both PD $\left(-0.12 \mathrm{~W} \mathrm{~m}^{-2}\right)$ and PI $\left(-0.21 \mathrm{~W} \mathrm{~m}^{-2}\right)$. In contrast, the SWCF change between the Default and G11Internal for PD is a factor of 10 smaller, which suggests a much smaller change to AIF by marine OA if the marine POA emissions are considered to be internally mixed with sea salt. As described in Sect. 3.2.4, the reduction of AIF 


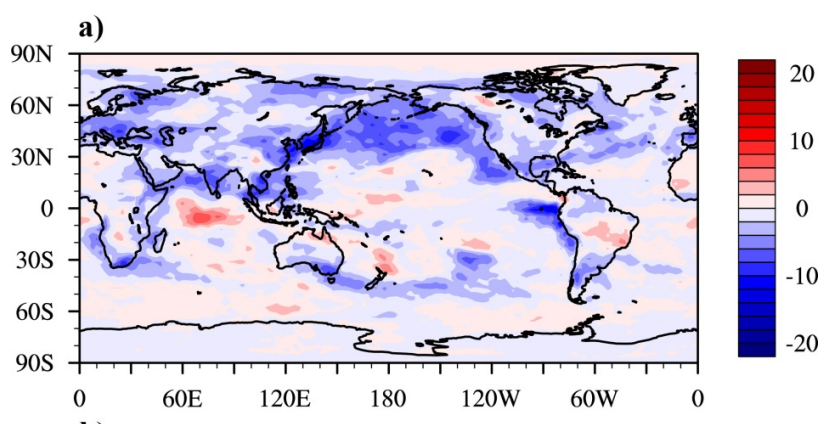

b)

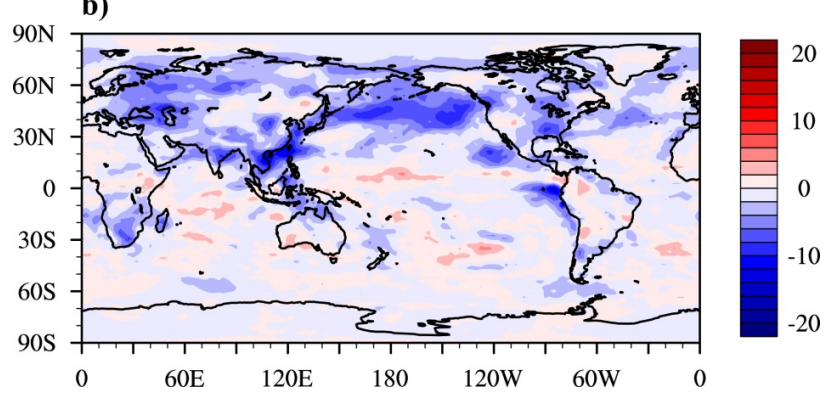

Fig. 3. Model predicted difference in the 10-yr average shortwave cloud forcing $\left(\mathrm{W} \mathrm{m}^{-2}\right.$ ) between the (a) Default-PI and Default and between the (b) G11-PI and G11 simulations.

due to marine organic aerosols mainly occurs due to an increase in background low-level CDNC. This result is consistent with Hoose et al. (2009) which showed lower predictions of changes in SWCF with an increase in the minimum CDNC or aerosol concentration. Figure $3 a$ and $b$ show that oceanic areas like the Southern Ocean and northern Atlantic Ocean, which have high marine organic emissions and low/moderate levels of CDNC, experience the largest decrease in the absolute value of AIF when marine organic aerosols are included. In the more heavily polluted oceanic region downwind of China where the AIF is the greatest, marine organic aerosols have little impact. As concentrations of marine organic aerosols are typically well below those of terrestrial and anthropogenic aerosols in all but "clean" marine air masses, it is not surprising that these areas are the most sensitive to their inclusion. Overall, our calculations suggest that the bi-directional feedbacks between marine organic aerosols, clouds and climate can have a non-trivial impact on the cloud albedo effect predicted by climate models (IPCC, 2007). Therefore, the inclusion of marine organic aerosols has the potential to improve model estimates of $\mathrm{CCN}$, cloud microphysics and model-predicted shortwave radiative forcing especially over remote marine regions.

\section{Conclusions}

A treatment of marine organic aerosols has been implemented into the CAM5 coupled with MAM-7 to examine their effects on cloud properties and radiative forcing. Re- sults show that marine organic aerosols can have large local effects on clouds (up to a $20 \%$ annual average increase in low-level in-cloud CDNC in the Southern Ocean, Northern Pacific and Northern Atlantic), especially during the summertime when chlorophyll- $a$ concentration ([Chl $a]$ ) is typically at a maximum. When these aerosols are included in model comparisons of pre-industrial (PI) and present day (PD) anthropogenic emissions, the model-predicted absolute value of anthropogenic aerosol indirect forcing (AIF) can be decreased by up to $0.09 \mathrm{~W} \mathrm{~m}^{-2}(7 \%)$. Predicted changes in low-level CDNC and shortwave cloud forcing due to marine organic aerosols are more sensitive to the mixing state of the primary marine organic aerosols (internal vs. external mixtures) than their hygroscopicity (chemistry). As both external and internal mixtures of marine organic aerosols and seasalt have been observed, this sensitivity to mixing state highlights the need for improved understanding of the emission processes and their implementation in global models. The global changes in cloud microphysical and radiative properties due to marine organic aerosols are higher in the simulations with preindustrial $\left[1.4 \mathrm{~cm}^{-3}(2.4 \%)\right.$ and $-0.21 \mathrm{~W} \mathrm{~m}^{-2}$ $(0.5 \%)$ for low level CDNC and SWCF, respectively] than present day emissions $\left[1.3 \mathrm{~cm}^{-3}(1.5 \%)\right.$ and $-0.12 \mathrm{~W} \mathrm{~m}^{-2}$ (0.3\%) for low level CDNC and SWCF, respectively]. This result is consistent with studies showing that pristine clouds have the highest susceptibility to increased aerosol concentrations (Platnick and Twomey, 1994). As climate models are sensitive to the background aerosol concentration and CDNC in remote marine areas (Menon et al., 2002), this study demonstrates the importance of accurate prediction of marine aerosol-cloud-climate interactions for future assessments of model-predicted extent of human-induced climate change.

\section{Supplementary material related to this article is available online at: http://www.atmos-chem-phys.net/12/ 6555/2012/acp-12-6555-2012-supplement.pdf.}

Acknowledgements. This research was supported by the Office of Science (BER), US Department of Energy, Grant No. DE-FG0208ER64508 and by NASA under award No. NNX11AG72G. BG is also supported by the NASA Earth and Space Science Fellowship (NESSF) Program. AN acknowledges support from NASA ACMAP and NSF CAREER awards. PNNL authors were funded by the US Department of Energy, Office of Science, Scientific Discovery through Advanced Computing (SciDAC) Program. The Pacific Northwest National Laboratory is operated for DOE by Battelle Memorial Institute under contract DE-AC06-76RLO 1830. We also thank the two anonymous reviewers for their helpful comments. 
Edited by: D. Spracklen

\section{References}

Abdul-Razzak, H. and Ghan, S. J.: A parameterization of aerosol activation: 2. Multiple aerosol types, J. Geophys. Res., 105, 68376844, 2000.

Albrecht, B.: Aerosols, Cloud Microphysics, and Fractional Cloudiness, Science, 245, 1227-1230, 1989.

Behrenfeld, M. J., O’Malley, R. T., Siegel, D. A., McClain, C. R., Sarmiento, J. L., Feldman, G. C., Milligan, A. J., Falkowski, P. G., Letelier, R. M., and Boss, E. S.: Climate-driven trends in contemporary ocean productivity, Nature, 444, 752-755, doi:10.1038/nature05317, 2006.

Bond, T. C., Bhardwaj, E., Dong, R., Jogani, R., Jung, S., Roden, C., Streets, D. G., and Trautmann, N. M.: Historical emissions of black and organic carbon aerosol from energy-related combustion, 1850-2000, Global Biogeochem. Cy., 21, GB2018, doi:10.1029/2006GB002840, 2007.

Bopp, L., Monfray, P., Aumont, O., Dufresne, J. L., Le Treut, H., Madec, G., Terray, L., and Orr, J. C.: Potential impact of climate change on marine export production, Global Biogeochem. Cy., 15, 81-99, 2001.

Chang, R. Y.-W., Liu, P. S. K., Leaitch, W. R., and Abbatt, J. P. D.: Comparison between measured and predicted CCN concentrations at Egbert, Ontario: Focus on the organic aerosol fraction at a semi-rural site, Atmos. Environ., 41, 8172-8182, 2007.

Facchini, M. C., Rinaldi, M., Decesari, S., Carbone, C., Finessi, E., Mircea, M., Fuzzi, S., Ceburnis, D., Flanagan, R., Nilsson, E., de Leeuw, G., Martino, M., Woeltjen J., and O'Dowd, C. D.: Primary sub-micron marine aerosol dominated by insoluble organic colloids and aggregates, Geophys. Res. Lett., 35, L17814, doi:10.1029/2008GL034210, 2008.

Fountoukis, C. and Nenes, A.: Continued development of a cloud droplet formation parameterization for global climate models, J. Geophys. Res., 110, D11212, doi:10.1029/2004JD005591, 2005.

Fuentes, E., Coe, H., Green, D., and McFiggans, G.: On the impacts of phytoplankton-derived organic matter on the properties of the primary marine aerosol - Part 2: Composition, hygroscopicity and cloud condensation activity, Atmos. Chem. Phys., 11, 25852602, doi:10.5194/acp-11-2585-2011, 2011.

Gantt, B., Meskhidze, N., Facchini, M. C., Rinaldi, M., Ceburnis, D., and O'Dowd, C. D.: Wind speed dependent size-resolved parameterization for the organic mass fraction of sea spray aerosol, Atmos. Chem. Phys., 11, 8777-8790, doi:10.5194/acp-11-87772011, 2011.

Ghan, S. J., Abdul-Razzak, H., Nenes, A., Ming, Y., Liu, X., Ovchinnikov, M., Shipway, B., Meskhidze, N., Xu, J., and Shi, X.: Droplet nucleation: Physically-based parameterizations and comparative evaluation, J. Adv. Model. Earth Syst., 3, M10001, doi:10.1029/2011MS000074, 2011.

Gregg, W. W., Conkright, M. E., Ginoux, P., O’Reilly, J. E., and Casey, N. W.: Ocean primary production and climate: global decadal changes, Geophys. Res. Lett., 30, 1809, doi:10.1029/2003GL016889, 2003.

Henson, S. A., Sarmiento, J. L., Dunne, J. P., Bopp, L., Lima, I., Doney, S. C., John, J., and Beaulieu, C.: Detection of anthropogenic climate change in satellite records of ocean chlorophyll and productivity, Biogeosciences, 7, 621-640, doi:10.5194/bg-7621-2010, 2010.

Hultin, K. A. H., Nilsson, E. D., Krejci, R., Mårtensson, E. M., Ehn, M., Hagström, Å., and de Leeuw, G.: In situ laboratory sea spray production during the Marine Aerosol Production 2006 cruise on the northeastern Atlantic Ocean, J. Geophys. Res., 115, D06201, doi:10.1029/2009JD012522, 2010.

Hoose, C., Kristjánsson, J. E., Iversen, T., Kirkevåg, A., Seland, Ø., and Gettelman, A.: Constraining cloud droplet number concentration in GCMs suppresses the aerosol indirect effect, Geophys. Res. Lett., 36, L12807, doi:10.1029/2009GL038568, 2009.

IPCC: The Physical Science Basis, in: Contribution of Working Group I of the Fourth Assessment Report of the Intergovernmental Panel on Climate Change, Cambridge University Press, Cambridge, UK, 2007.

Junker, C. and Liousse, C.: A global emission inventory of carbonaceous aerosol from historic records of fossil fuel and biofuel consumption for the period 1860-1997, Atmos. Chem. Phys., 8, 1195-1207, doi:10.5194/acp-8-1195-2008, 2008.

Kiliyanpilakkil, V. P. and Meskhidze, N.: Deriving the effect of wind speed on clean maritime aerosol optical properties using the A-Train satellites, Atmos. Chem. Phys., 11, 11401-11413, doi:10.5194/acp-11-11401-2011, 2011.

Lamarque, J.-F., Bond, T. C., Eyring, V., Granier, C., Heil, A., Klimont, Z., Lee, D., Liousse, C., Mieville, A., Owen, B., Schultz, M. G., Shindell, D., Smith, S. J., Stehfest, E., Van Aardenne, J., Cooper, O. R., Kainuma, M., Mahowald, N., McConnell, J. R., Naik, V., Riahi, K., and van Vuuren, D. P.: Historical (1850-2000) gridded anthropogenic and biomass burning emissions of reactive gases and aerosols: methodology and application, Atmos. Chem. Phys., 10, 7017-7039, doi:10.5194/acp10-7017-2010, 2010.

Liu, X. and Wang, J.: How important is organic aerosol hygroscopicity to aerosol indirect forcing, Environ. Res. Lett., 5, 044010, doi:10.1088/1748-9326/5/4/044010, 2010.

Liu, X., Easter, R. C., Ghan, S. J., Zaveri, R., Rasch, P., Shi, X., Lamarque, J.-F., Gettelman, A., Morrison, H., Vitt, F., Conley, A., Park, S., Neale, R., Hannay, C., Ekman, A. M. L., Hess, P., Mahowald, N., Collins, W., Iacono, M. J., Bretherton, C. S., Flanner, M. G., and Mitchell, D.: Toward a minimal representation of aerosols in climate models: description and evaluation in the Community Atmosphere Model CAM5, Geosci. Model Dev., 5, 709-739, doi:10.5194/gmd-5-709-2012, 2012.

Lohmann, U. and Lesins, G.: Stronger constraints on the anthropogenic indirect aerosol effect, Science, 298, 1012-1016, 2002.

Menon, S., Del Genio, A. D., Koch, D., and Tselioudis, G.: GCM Simulations of the aerosol indirect effect: Sensitivity to cloud parameterization and aerosol burden. J. Atmos. Sci., 59, 692713, 2002.

Meskhidze, N. and Nenes, A.: Phytoplankton and cloudiness in the Southern Ocean, Science, 314, 1419-1423, doi:10.1126/science.1131779, 2006.

Meskhidze, N., Xu, J., Gantt, B., Zhang, Y., Nenes, A., Ghan, S. J., Liu, X., Easter, R., and Zaveri, R.: Global distribution and climate forcing of marine organic aerosol: 1. Model improvements and evaluation, Atmos. Chem. Phys., 11, 11689-11705, doi:10.5194/acp-11-11689-2011, 2011.

Moore, R. H., Ingall, E., Sorooshian, A., and Nenes, A.: Molar mass, surface tension and droplet growth kinetics of marine or- 
ganics from measurement of $\mathrm{CCN}$ activity, Geophys. Res. Lett., 35, L07801, doi:10.1029/2008GL033350, 2008.

Moore, M. J. K., Furatani, H., Roberts, G. C., Moffet, R. C., Giles, M. K., Palenik, B., and Prather, K. A.: Effect of organic compounds on cloud condensation nuclei $(\mathrm{CCN})$ activity of sea spray aerosol produced by bubble bursting, Atmos. Environ., 45, 74627469, doi:10.1016/j.atmosenv.2011.04.034, 2011.

Neale, R. B., Chen, C.-C., Gettelman, A., Lauritzen, P. H., Park, S., Williamson, D. L., Conley, A. J., Garcia, R., Kinnison, D., Lamarque, J.-F., Marsh, D., Mills, M., Smith, A. K., Tilmes, S., Vitt, F., Cameron-Smith, P., Collins, W. D., Iacono, M. J., Easter, R. C., Ghan, S. J., Liu, X., Rasch, P. J., and Taylor, M. A.: Description of the NCAR Community Atmosphere Model (CAM 5.0), Tech. Note NCAR/TN-486+STR, Natl. Cent. for Atmos. Res., Boulder, CO, USA, 2010.

Novakov, T. and Penner, J. E., Large contribution of organic aerosols to cloud condensation nuclei concentrations, Nature, 365, 823-826, 1993.

Novakov, T., Corrigan, C. E., Penner, J. E., Chuang, C. C., Rosario, O., and Mayel Bracero, O. L.: Organic aerosols in the Caribbean trade winds: A natural source?, J. Geophys. Res., 102, 21307 23313, 1997

O’Dowd, C. D., Facchini, M. C., Cavalli, F., Ceburnis, D., Mircea, M., Decesari, S., Fuzzi, S., Yoon, Y. J., and Putaud, J. P.: Biogenically driven organic contribution to marine aerosol, Nature, 431, 676-680, 2004.

Ovadnevaite, J., Ceburnis, D., Martucci, G., Bialek, J., Monahan, C., Rinaldi, M., Facchini, M. C., Berresheim, H., Worsnop, D. R., and O'Dowd, C.: Primary marine organic aerosol: A dichotomy of low hygroscopicity and high CCN activity, Geophys. Res. Lett., 38, L21806, doi:10.1029/2011GL048869, 2011.

Petters, M. D. and Kreidenweis, S. M.: A single parameter representation of hygroscopic growth and cloud condensation nucleus activity, Atmos. Chem. Phys., 7, 1961-1971, doi:10.5194/acp-71961-2007, 2007.

Platnick, S. and Twomey, S.: Determining the susceptibility of cloud albedo to changes in droplet concentration with the advanced very high-resolution radiometer, J. Appl. Meteorol., 33, 334-347, 1994.
Prenni, A. J., Petters, M. D., Kreidenweis, S. M., DeMott, P. J., and Ziemann, P. J.: Cloud droplet activation of secondary organic aerosol, J. Geophys. Res.-Atmos., 112, D10223, doi:10.1029/2006JD007963, 2007.

Roelofs, G. J.: A GCM study of organic matter in marine aerosol and its potential contribution to cloud drop activation, Atmos. Chem. Phys., 8, 709-719, doi:10.5194/acp-8-709-2008, 2008.

Svenningsson, B., Rissler, J., Swietlicki, E., Mircea, M., Bilde, M., Facchini, M. C., Decesari, S., Fuzzi, S., Zhou, J., Mønster, J., and Rosenørn, T.: Hygroscopic growth and critical supersaturations for mixed aerosol particles of inorganic and organic compounds of atmospheric relevance, Atmos. Chem. Phys., 6, 1937-1952, doi:10.5194/acp-6-1937-2006, 2006.

Twomey, S. A.: The influence of pollution on the shortwave albedo of clouds, J. Atmos. Sci., 34, 1149-1152, 1977.

Wang, J., Lee, Y.-N., Daum, P. H., Jayne, J., and Alexander, M. L.: Effects of aerosol organics on cloud condensation nucleus (CCN) concentration and first indirect aerosol effect, Atmos. Chem. Phys., 8, 6325-6339, doi:10.5194/acp-8-6325-2008, 2008.

Wang, M., Ghan, S., Ovchinnikov, M., Liu, X., Easter, R., Kassianov, E., Qian, Y., and Morrison, H.: Aerosol indirect effects in a multi-scale aerosol-climate model PNNL-MMF, Atmos. Chem. Phys., 11, 5431-5455, doi:10.5194/acp-11-5431-2011, 2011.

Westervelt, D. M., Moore, R. H., Nenes, A., and Adams, P. J.: Effect of primary organic sea spray emissions on cloud condensation nuclei concentrations, Atmos. Chem. Phys., 12, 89-101, doi:10.5194/acp-12-89-2012, 2012.

Yoon, Y. J., Ceburnis, D., Cavalli, F., Jourdan, O., Putaud, J. P., Facchini, M. C., Decesari, S., Fuzzi, S., Sellegri, K., Jennings, S. G., and O'Dowd, C. D.: Seasonal characteristics of the physicochemical properties of North Atlantic marine atmospheric aerosols, J. Geophys. Res.-Atmos., 112, D04206, doi:10.1029/2005JD007044, 2007. 